\title{
PENGARUH DOSIS SUBLETAL IMIDAKLOPRID TERHADAP KESINTASAN POPULASI WERENG COKLAT PADA VARIETAS PADI RENTAN DAN TAHAN
}

\author{
Endang Sri Ratna ${ }^{1}$, Angga Satria Firmansyah ${ }^{1}$, \& Rahmini $^{2}$ \\ ${ }^{1}$ Departemen Proteksi Tanaman, Fakultas Pertanian, Institut Pertanian Bogor, \\ Jl. Kamper, Kampus IPB Dramaga, Bogor 16680 \\ ${ }^{2}$ Balai Besar Penelitian Tanaman Padi. Jalan Raya Sukamandi No 9, Sukamandi, Subang. \\ E-mail: esratna@gmail.com
}

\begin{abstract}
Sublethal dose effect of imidacloprid on the survival of brown planthoppers on resistant and susceptible rice varieties. Imidacloprid insecticides and resistant rice varieties are commonly used to control the the rice brown planthopper (BPH) Nilaparvata lugens in the field. The aim of this research was to evaluate the resistance of $N$. lugens to imidacloprid and the influence of sublethal dose of the insecticide applied to a certain resistant rice varieties on the survival of BPH. The experiment was conducted in a greenhouse trial at Indonesian Center for Rice Research, Sukamandi, West Java. Each pair of adult BPH were infested on three rice varieties Ciherang, Inpari 13, and Pelita, and then followed by spraying five doses of imidacloprid. The the effective dose rate of imidacloprid on $\mathrm{BPH}$ was determined by the value of $\mathrm{LD}_{95}$ compared with the recommended dose $\left(20 \mathrm{~g}_{\text {a.i. }} \mathrm{ha}^{-1}\right)$. The nymphal survival was concidered as a result of the applied sublethal doses. The numbers of nymphal progenies were observed until two peaks populations of both first and second generations. The insecticide then was applied at $\mathrm{LD}_{50}$ dose equivalent on adult $\mathrm{BPH}$ of the second generation. The number of laid eggs and the abnormal egg shapes were counted. Imidacloprid doses that were unefffective against $\mathrm{BPH}$ showed by the values of $\mathrm{LD}_{95}$ were 1224.3, 2799.0, dan 4692.8 $\mathrm{g}$ a.i. ha ${ }^{-1}$ at Ciherang, Inpari 13 dan Pelita rice varieties, respectively. Seven days after application of imidacoprid, about 70$90 \%$ of adult BPH still survived. Sublethal dosages of imidacloprid tended to increase the survival of BPH on a resistant rice variety of Inpari 13, as reflected by the number of nymphal progeny of 156-169 BPH/plant at the first population peak. Imidacloprid treatment increased the number of laid egg, but had no effect on the egg sterility.
\end{abstract}

Key words: effectiveness, Nilaparvata lugens, oviposition, population survival

\begin{abstract}
ABSTRAK
Pengaruh dosis subletal imidakloprid terhadap kesintasan populasi wereng coklat pada varietas padi rentan dan tahan. Insektisida imidakloprid dan varietas padi tahan wereng sering digunakan untuk mengendalikan populasi hama wereng batang coklat (WBC) Nilaparvata lugens di lapangan. Penelitian ini bertujuan menguji tingkat ketahanan WBC terhadap insektisida imidakloprid dan pengaruh dosis subletal terhadap sintasan populasi WBC pada varietas padi yang telah diketahui tipe ketahanannya. Penelitian dilaksanakan di rumah kaca Pusat Penelitian Padi Indonesia, Sukamandi. Sepasang imago WBC diinfestasikan pada tiga varietas padi (Ciherang, Inpari 13, dan Pelita), kemudian diberi lima dosis perlakuan imidakloprid. Keefektifan imidakloprid terhadap WBC ditentukan dari nilai $\mathrm{LD}_{95}$ relatif terhadap dosis anjuran penggunan di lapangan $20 \mathrm{~g}$ b.a./ha. Nimfa yang lolos hidup dari pengujian ini dianggap sebagai perlakuan dosis subletal pada pengujian selanjutnya. Jumlah nimfa diamati hingga dua puncak populasi generasi ke-1 dan ke-2. Dosis perlakuan $\mathrm{LD}_{50}$ diujikan kembali pada imago WBC generasi ke-2. Jumlah telur yang diletakkan dan bentuk telur abnormal dihitung. Imidakloprid tidak efektif mengendalikan WBC, ditunjukkan dengan nilai $\mathrm{LD}_{95}$ berturut-turut sebesar 1224.3, 2799.0, dan $4692.8 \mathrm{~g}$ b.a./ha pada varietas Ciherang, Inpari 13, dan Pelita. Setelah 7 hari perlakuan imidakloprid, sekitar 70-90\% imago WBC masih bertahan hidup. Dosis subletal imidakloprid cenderung meningkatkan sintasan WBC pada varietas tahan Inpari 13 yang tercermin dari capaian jumlah nimfa 156-169 ekor/rumpun pada puncak populasi pertama. Dosis subletal imidakloprid memicu peletakan jumlah telur, namun tidak berpengaruh terhadap fertilitas telur WBC.
\end{abstract}

Kata kunci: keefektifan, Nilaparvata lugens, oviposisi, sintasan populasi 


\section{PENDAHULUAN}

Insektisida organik sintetik, salah satu diantaranya adalah anggota dari kelompok senyawa neonikotinoid hingga kini masih digunakan untuk mengendalikan hama pada tanaman padi (Cox, 2001; Ghosh et al., 2014). Pada umumnya, penggunaan insektisida yang kurang tepat seringkali menimbulkan kasus resurjensi seperti pada wereng batang coklat (WBC) Nilaparvala lugens Stål (Chelliah \& Heinrichs, 1980; Reissig et al., 1982; Gu et al., 1984; Gao et al., 1988; Wang et al., 1994). Dosis subletal insektisida dilaporkan dapat mengakibatkan peningkatan pertumbuhan dan produktivitas hama (Bao et al., 2009; Chelliah \& Heinrichs 1980; Heinrich \& Mochida, 1984). Kejadian resurjensi akibat penggunaan insektisida ini di lapangan ditandai dengan berkurangnya musuh alami dan peningkatan fekunditas hama (Fabellar \& Heinrich, 1986; Gao et al., 1988).

WBC kini telah menjadi hama penting dan endemis di Indonesia. Menurut Bottrell \& Schoenly (2012), hama ini mulai menjadi masalah serius pada budidaya padi sejak adanya gerakan revolusi hijau. Nimfa dan imago WBC hidup berkelompok dan mengisap cairan tanaman pada bagian pangkal rumpun tanaman padi, sehingga menyebabkan kerusakan ekonomi yang parah (Baehaki, 2011). Gelaja kerusakan oleh populasi WBC yang tinggi dapat mengakibatkan hopperburn, yaitu daun mengering dan rumpun padi kerdil, sehingga tanaman menjadi puso. Penggunaan insektisida imidakloprid masih menjadi andalan utama dalam pengendalian WBC (Wen et al., 2009). Oleh karena itu, beberapa kasus resurjensi telah dilaporkan karena terbentuknya populasi resisten akibat penggunaan insektisida imidakloprid dan piretroid yang berlebihan di lapangan (Liu et al., 2003; Nauen \& Denholm, 2005; Matsumura et al., 2008; Matsumura et al., 2009). Kasus resistensi WBC terhadap imidakloprid telah banyak dilaporkan di daerah Cina dan Asia Tenggara, namun belum terdeteksi di India dan Filipina (Ghosh et al., 2014; Matsumura et al., 2008). Peningkatan tingkat resistensi WBC mencapai 14 kali lipat setelah 27 generasi (Wang et al., 2008) atau bahkan hingga 250 kali lipat setelah 37 generasi (Liu \& Han, 2006). Hal ini sering dikaitkan dengan tingginya frekuensi aplikasi insektisida imidakloprid di lapangan. Resurgensi populasi WBC juga dapat dipicu karena sifat ketidak stabilan tingkat resistensinya yang sangat tinggi pada populasi lapang disertai tingkat kerentanannya yang cepat pulih saat tidak terpapar imidakloprid (Wen et al., 2009; Liu \& Han, 2006; Yang et al., 2014).
Pengendalian populasi WBC selain menggunakan insektisida sering dikaitkan dengan seleksi ketahanan dan kerentanan tanaman terhadap wereng tersebut (Yin et al., 2008). Seperti contohnya insektisida deltametrin dapat meningkatkan populasi WBC pada varietas padi rentan dibandingkan padi tahan. Azzam et al. (2011) melaporkan bahwa penggunaan insektisida imidakloprid dapat berpotensi meningkatkan populasi WBC pada varietas tahan. Cheng et al. (2012) melaporkan bahwa imidakloprid dapat mengubah kerentanan tanaman terhadap serangan WBC. Penggunaan insektisida yang sangat intensif dilakukan oleh petani yang umumnya menanam varietas tersebut diatas diduga dapat mengubah respons ketahanan terhadap serangan WBC yang berimplikasi pada peningkatan populasinya di lapangan. Oleh karena itu perlu dilakukan pengujian tingkat keefektifan imidakloprid terhadap WBC serta implikasi dosis subletal terhadap pertumbuhan populasi, jumlah peletakan telur dan abnormalitas bentuk telur WBC pada varietas rentan maupun tahan.

\section{METODE PENELITIAN}

Tempat dan Waktu. Penelitian ini dilaksanakan di rumah kaca Balai Besar Padi, Sukamandi, Kabupaten Subang. Penelitian dilakukan mulai bulan Februari 2014 sampai dengan Juni 2014.

Penyediaan Tanaman Padi. Tiga varietas padi (Oryza sativa $\mathrm{L}$.), yaitu Ciherang, Inpari 13, dan Pelita digunakan untuk pemeliharaan wereng dan pengujian insektisida. Varietas Ciherang diketahui tahan terhadap biotipe 2 dan agak tahan terhadap biotipe 3 (Suprihatno et al., 2009), sedangkan Inpari 13 diketahui tahan dan Pelita rentan terhadap tiga biotipe wereng coklat, yaitu biotipe 1,2 , dan 3 (Rahmini et al., 2012). Benih padi diperoleh dari Balai Besar Padi, Sukamandi. Setiap dua batang benih ditanam di dalam ember plastik berisi tanah sawah berdiameter $30 \mathrm{~cm}$ yang disungkup kurungan plastik silinder bertutupkan kain kasa setinggi $100 \mathrm{~cm}$. Tanaman padi dipelihara sebaik-baiknya dengan dilakukan penyiraman setiap dua hari sekali dan pemberian pupuk urea dan SP-36 dengan dosis sebesar $100 \mathrm{~kg} / \mathrm{ha}$ dan $100 \mathrm{~kg} / \mathrm{ha}$ pada 2 dan 4 MST.

Penyediaan Wereng Batang Coklat. Nimfa instar 3 dan 4 wereng batang coklat (WBC) Nilaparvata lugens Stål dikoleksi dari populasi lapang pada pertanaman padi varietas Ciherang di daerah Sukamandi, Kabupaten Subang. Nimfa tersebut kemudian dipelihara dan diperbanyak di rumah kaca setiap varietas uji tersebut 
di dalam sebuah ember bersungkup kain kasa hingga terbentuk imago. Imago yang baru berganti kulit digunakan sebagai serangga uji.

\section{Keefektifan Insektisida Imidakloprid Mengendalikan Populasi WBC. Lima dosis} insektisida berbahan aktif imidakloprid berturut-turut $3200,1600,800,400,200$, dan $0 \mathrm{~g} / \mathrm{ha}$ (kontrol) diaplikasikan melalui metode penyemprotan pada tanaman berumur 4 MST yang telah diinfestasi sepasang imago WBC brakiptera di dalam ember yang disungkup kain kasa. Dosis perlakuan tersebut ditentukan melalui uji pendahuluan pada varietas Ciherang dengan mengacu pada dosis anjuran insektisida bersimbol formulasi $5 \mathrm{WP}$ tertulis di dalam label pestisida, yaitu $400 \mathrm{~g} / \mathrm{ha}$ atau setara dengan $20 \mathrm{~g}$ bahan aktif/ha dengan harapan dapat mematikan sebagian besar (95\%) populasi wereng uji. Pengacuan pada dosis anjuran digunakan untuk menentukan keefektifan insektisida yang diaplikasikan (Ahmed et al., 2014). Aplikasi insektisida dilakukan setelah 24 jam wereng tersebut dinfestasikan pada tanaman uji. Kelima dosis perlakuan dan kontrol di atas masing-masing diaplikasikan pada tiga varietas padi dengan ulangan 10 kali. Kematian WBC diamati dan dicatat pada $24 \mathrm{jam}, 48$ jam dan $72 \mathrm{jam}$ setelah perlakuan (JSP) insektisida. Data mortalitas WBC uji yang diperoleh pada 72 JSP diolah melalui analis probit (LeOra Software, 1987). Tingkat mortalitas WBC ditentukan dengan nilai $\mathrm{LD}_{50}$ dan $\mathrm{LD}_{95}$. Nilai $\mathrm{LD}_{50}$ digunakan untuk acuan perlakuan berikutnya, sedangkan nilai $\mathrm{LD}_{95}$ digunakan untuk menentukan tingkat keefektifan imidakloprid terhadap WBC dengan membandingkannya pada dosis anjuran.

Monitoring Sintasan Populasi WBC Perlakuan Subletal Imidakloprid. WBC yang berhasil lolos dari paparan kelima dosis perlakuan insektisida di atas dipelihara lebih lanjut hingga populasi berkembang pada masing-masing varietas tanaman. Jumlah populasi WBC yang berkembang diamati dan dihitung dengan bantuan alat hand tally counter setiap minggu hingga akhir percobaan. Puncak populasi generasi pertama dan kedua setelah aplikasi imidakloprid pada ketiga varietas padi tersebut di atas dihitung dan dibandingkan rata-rata jumlah nimfa dan simpangan bakunya, dengan menggunakan program Microsof Excel 97-2004.

\begin{abstract}
Aplikasi Dosis Subletal Imidakloprid terhadap Peletakkan Telur Wereng. Setiap dosis insektisida yang ditentukan dari nilai $\mathrm{LD}_{50}$ hasil analisis probit pada pengujian masing-masing tiga varietas padi di atas diaplikasikan pada koloni WBC generasi ke-2 hasil perlakuan sebelumnya. Setiap 10 induk betina dinfestasikan pada tiga varietas padi perlakuan yang masing-masing disertakan perlakuan kontrol. Peletakan wereng pada tanaman sama seperti pengujian di atas. Telur yang diletakkan oleh betina yang berhasil lolos hidup diamati pada 72 JSP dengan cara membedah jaringan tanaman padi dan mengamatinya di bawah mikroskop binokuler. Jumlah telur yang diletakkan oleh betina dihitung menggunakan hand tally counter.
\end{abstract}

\section{HASIL DAN PEMBAHASAN}

Keefektifan Wereng terhadap Insektisida Imidakloprid. Berdasarkan hasil aplikasi imidakloprid terhadap populasi WBC yang diinfestasikan pada tiga varietas padi agak tahan Ciherang, tahan Inpari 13, dan rentan Pelita menunjukkan bahwa di lapangan terjadi peningkatan ketahanan WBC terhadap insektisida tersebut (Tabel 1). Kinerja bahan aktif imidakloprid ditunjukkan dengan mortalitas WBC yang mulai terjadi pada 24 jam setelah perlakuan (JSP) dan optimal dicapai pada 72 JSP. Nilai $\mathrm{LD}_{50}$ berturut-turut paling tinggi dijumpai pada perlakuan penyemprotan WBC uji pada kultivar tanaman Pelita, Inpari 13, dan terendah pada Ciherang yaitu sebesar 4.441, 1.289, dan $1.033 \mathrm{~g} / \mathrm{ha}$. Keefektifan insektisida dinyatakan dalam nilai $\mathrm{LD}_{95}$ yang masing-masing menunjukkan penurunan dibandingkan dosis anjuran, yakni $400 \mathrm{~g} / \mathrm{ha}$. Dosis insektisida

Tabel 1. Toksisitas insektisida imidakloprid terhadap imago wereng coklat pada 72 JSP

\begin{tabular}{lccccc}
\hline Varietas & $\mathrm{a} \pm \mathrm{GB}$ & $\mathrm{b} \pm \mathrm{GB}$ & $\begin{array}{c}\mathrm{LD}_{50}(\mathrm{SK} 95 \%) \\
(\mathrm{g} / \mathrm{ha})\end{array}$ & $\begin{array}{c}\mathrm{LD}_{95}(\mathrm{SK} 95 \%) \\
(\mathrm{g} / \mathrm{ha})\end{array}$ & $\begin{array}{c}\text { Perbandingan } \\
\text { dosis anjuran } \\
\text { dengan } \mathrm{LD}_{95} *\end{array}$ \\
\hline Inpari 13 & $-4,00 \pm 1,36$ & $1,29 \pm 0,45$ & $1289(766-2605)$ & $24486(7347-0,17 \mathrm{E})$ & $1: 61$ \\
Ciherang & $-5,26 \pm 1,03$ & $1,74 \pm 0,35$ & $1033(612,2-1986,4)$ & $5598(-)$ & $1: 14$ \\
Pelita & $-3,52 \pm 1,43$ & $0,97 \pm 0,46$ & $4441(2404,1-20306)$ & $93857(-)$ & $1: 235$ \\
\hline
\end{tabular}

$\mathrm{a}=$ intersep regresi probit, $\mathrm{b}=$ kemiringan regresi probit, $\mathrm{GB}=$ galat baku, $\mathrm{SK} 95 \%=$ nilai kisaran dosis pada selang kepercayaan $95 \%$. Dosis anjuran aplikasi $=400 \mathrm{~g} / \mathrm{ha}$. 
imidakloprid yang diaplikasikan pada WBC memberikan respon ketahanan yang agak berlainan saat dinfestasikan pada varietas tanaman berbeda. Kinerja imidakloprid dalam menekan populasi WBC yang diinfestasikan pada tanaman rentan Pelita menunjukkan tingkat ketidakefektifan paling tinggi 235 kali lipat dibandingkan pada tanaman tahan Inpari 13 dan Ciherang yang relatif lebih rendah berturut-turut 61 dan 14 kali lipat setelah diberi perlakuan insektisida. Ketidakefektifan perlakuan imidakloprid pada percobaan ini diduga karena WBC di lapangan khususnya di daerah Subang sudah resisten terhadap insektisida tersebut. Resistensi insektisida dinyatakan sebagai perubahan sensitifitas populasi hama yang diwariskan, tercermin dari berulangnya ketidakberhasilan pengendalian yang diharapkan saat menggunakan produk pestisida pada label yang direkomendasikan terhadap hama tersebut (IRAC, (2007). Perkembangan resistensi WBC terhadap insektisida imidakloprid sangat berkaitan dengan penggunaan bahan kimia tersebut diaplikasikan di lapangan, terutama populasi gen resisten meningkat dengan pesat setelah penggunaan secara kontinyu paling sedikit selama 13 tahun (Wang et al., 2008). Potensi keberadaan populasi resisten terhadap imidakloprid di lapangan sangat tinggi terjadi di Indonesia, mengingat insektisida tersebut telah digunakan petani untuk mengendalikan WBC sejak tahun 1994 (Cox, 2001).

WBC yang diujikan pada tanaman rentan Pelita menunjukkan peningkatan ketahanan yang paling nyata bila dibandingkan varietas tahan Inpari 13. Hal ini diduga bahwa tubuhnya mendapatkan nutrisi yang relatif baik dan mengalami pemulihan kebugaran pada tanaman varietas rentan, sehingga lebih tahan terpapar oleh tekanan perlakuan pestisida. Menurut Raymond et al. (2011), serangga yang memiliki gen resisten terhadap insektisida apabila dipaparkan pada varietas tanaman rentan, kemudian diberi perlakuan insektisida, maka tingkat keberhasilan hidup serangga tersebut menjadi lebih tinggi. WBC yang diberi pakan tanaman varietas rentan menyebabkan peningkatan populasi brakhiptera serta percepatan reproduksi (Yin et al., 2008) dan hal ini dapat dikaitkan dengan kemampuan makan yang tinggi dibandingkan varietas tanaman tahan (Cruz et al., 2011; Rahmini et al., 2012). Menurut Liu \& Han (2006), kebugaran WBC pada varietas rentan lebih tinggi 5-10 kali lipat dibandingkan varietas tahan. Ketahanan WBC terhadap imidakloprid pada varietas Ciherang lebih rendah dibandingkan Inpari 13, diduga karena wereng ini berasal dari populasi lapangan pada tanaman yang sama. Selain itu WBC uji yang digunakan pada perlakuan telah beradaptasi 10 tahun dengan kondisi lapangan setelah pelepasan varietas yang pada saat tersebut dianggap tahan dibandingkan Inpari 13 yang relatif paling baru. Pemeliharaan WBC saat perbanyakan tanpa terpapar insektisida diduga memberikan adaptasi fisiologi, sehingga memberikan respon berbeda terhadap kebugarannya yang dalam hal ini tidak dapat dijelaskan dengan pasti. Walaupun demikian, resistensi wereng terhadap imidakloprid terbentuk akibat penggunaannya yang sering dilakukan di lapangan (Wang et al., 2008), sedangkan penghentian pemaparannya dapat dengan cepat memulihkan kerentanannya terhadap insektisida tersebut (Liu \& Han, 2006). Hal ini mengindikasikan bahwa respon penurunan ketahanan wereng terhadap insektisida dinduksi oleh adaptasi tanaman tahan di lapangan.

\section{Pengaruh Subletal Dosis Imidakloprid terhadap Sintasan Populasi Wereng. Persentase imago WBC} yang bertahan hidup pada minggu pertama pengamatan setelah perlakuan insektisida imidakloprid ditunjukkan pada Tabel 2. Perlakuan dosis tertinggi imidakloprid (3200 $\mathrm{g} / \mathrm{ha}$ ) menghasilkan keloloshidupan WBC terendah, yakni $20 \%$ pada varietas tahan dan $45 \%$ pada varietas rentan yang relatif sangat berbeda dibandingkan kontrol yang mencapai kisaran $85-90 \%$. Keloloshidupan tertinggi WBC uji dijumpai pada varietas Inpari 13 dan Ciherang yakni pada dosis $400 \mathrm{~g} / \mathrm{ha}$ masing masing sebesar $70 \%$

Tabel 2. Jumlah induk wereng yang bertahan hidup satu minggu setelah berhasil terseleksi dari dosis letal imidakloprid

\begin{tabular}{llccc}
\hline \multirow{2}{*}{ Dosis insektisida (g/ha) } & \multicolumn{3}{c}{ Persentase wereng hidup (\%) } \\
\cline { 3 - 5 } & & Inpari 13 & Ciherang & Pelita \\
\hline Imidakloprid & 3200 & 20 & 0 & 45 \\
& 1600 & 40 & 40 & 60 \\
& 800 & 60 & 45 & 80 \\
& $400^{*}$ & 70 & 90 & 75 \\
Kontrol & 200 & 60 & 85 & 75 \\
& 0 & 85 & 90 & 90 \\
\hline
\end{tabular}

* dosis anjuran aplikasi yang digunakan petani. 
hingga 90\%, sedangkan pada varietas Pelita pada dosis $800 \mathrm{~g} / \mathrm{ha}$. Walaupun terdapat perkecualian bahwa keloloshidupan yang menurun pada dosis $200 \mathrm{~g} / \mathrm{h}$, diduga karena variasi kebugaran tubuh individu WBC uji yang tidak seragam, mengingat sumber wereng uji diambil langsung dari populasi lapang. Hal ini menunjukkan bahwa semakin tinggi dosis perlakuan semakin rendah populasi WBC yang bertahan hidup. Dengan demikian, daya racun imidakloprid masih bertahan di dalam tubuh WBC hingga hari ketujuh. Imidakloprid dapat bertahan dengan waktu paruh akibat fotolisis selama 39 hari di permukaan tanah dan 26,5-229 hari dalam keadaan terikat di dalam butiran tanah (Fossen, 2006). Hasil penelusuran dengan atom $\mathrm{C}^{14}$ radioaktif, berturut-turut 94-96\%, 77-88\%, dan 53-62\% molekul kimia imidakloprid masih terdeteksi di dalam tanah pot yang ditanami tanaman kapas setelah 7, 14 dan 21 hari aplikasi, dan sekitar 1,8 -6,8\% berfluktuasi diserap oleh tanaman (ElHamady et al., 2008).

Jumlah populasi nimfa WBC yang teramati pada 2 MSP imidakloprid relatif paling tinggi pada varietas Ciherang ditunjukkan pada Gambar 1A. Rerata jumlah nimfa yang terbentuk mulai dosis aplikasi tertinggi 1600 g/ha hingga terendah $200 \mathrm{~g} / \mathrm{ha}$ berkisar antara 64-137 nimfa/betina yang relatif lebih rendah dibandingkan kontrol (53 ekor/betina). Apabila ditinjau dari ketahanan WBC yang rendah berdasarkan nilai $\mathrm{LD}_{50}$ (Tabel 1), maka perlakuan imidakloprid berimplikasi terhadap peningkatan populasi generasi keturunannya yang timbul kemudian. Hal ini berarti bahwa imago WBC yang sensitif terhadap peracunan imidakloprid memberikan kontribusi peningkatan jumlah nimfa pada varietas tersebut. Wu et al. (2001) melaporkan bahwa pemberian insektisida bisultap pada tanaman padi dapat menurunkan kandungan sukrosa 5 hari setelah aplikasi insektisida. Menurut Buenaflor et al. (1981), penurunan perbandingan unsur $\mathrm{C}$ terhadap $\mathrm{N}$ dapat menstimulasi makan, sehingga meningkatkan populasi wereng. Interaksi serangga dengan tanaman seringkali dipengaruhi oleh asam amino spesifik yang berpengaruh terhadap penurunan perilaku probing dan peningkatan perilaku mengisap cairan pakan, namun ada pula yang berperan sebagai penghambat makan. Keberadaan kandungan asam $\gamma$-aminobutrirat dilaporkan tinggi pada varietas padi tahan Mudgo (Sogawa \& Pathak, 1970), yang kemudian nyata menurun setelah tanaman diberi perlakuan bisultap dibandingkan tanaman tanpa perlakuan. Menurut Wu et al. (2004) perlakuan insektisida bisultap dapat menurunkan kandungan asam oksalat dan laju fotosintesis. Asam oksalat diketahui sebagai bahan antifidan yang berperan dalam mekanisme pertahanan tanaman terhadap serangan WBC (Nagata
\& Hayakawa, 1998), sedangkan penurunan laju fotosintesis akan mengurangi kebugaran tanaman, sehingga menjadi lebih rentan terhadap serangan wereng. Menurut Rahmini et al. (2012) kandungan sukrosa lebih rendah pada varietas tahan Inpari 13 dan PTB 33 dibandingkan varietas rentan TN1, sebaliknya kandungan oksalat lebih tinggi pada varietas tahan Inpari 13 dan PTB 33 dibandingkan varietas rentan TN1.

Sintasan hidup nimfa pada populasi generasi I dan II ditunjukkan pada Gambar 1B dan 1C. Secara umum, populasi WBC pada tanaman tahan Impari 13 dan agak tahan Ciherang cenderung lebih tinggi dibandingkan varietas rentan Pelita. Perlakuan imidakloprid dosis tertinggi $3200 \mathrm{~g} / \mathrm{ha}$ menimbulkan kematian seluruh induk WBC pada tanaman Ciherang, namun masih mampu menekan pertumbuhan populasi hingga dua generasi pada varietas Pelita dan Inpari 13. Puncak populasi generasi pertama umumnya terjadi pada minggu ke-3 (60\%) hingga ke-5, sedangkan puncak populasi generasi berikutnya berada pada minggu ke-6 \& 7 (77\%) hingga ke-8 setelah aplikasi insektisida.

Jumlah nimfa WBC pada puncak populasi generasi pertama relatif tinggi pada varietas tahan Inpari 13 saat diberi aplikasi imidaklorid dosis rendah 200-400 g/ha dan kontrol, yaitu sebesar 156-169 ekor/rumpun, dan varietas agak tahan Ciherang pada aplikasi dosis $200 \mathrm{~g} /$ ha sebesar 202 ekor/rumpun, walaupun jumlah nimfa masih tampak tinggi terjadi pada aplikasi dosis tinggi 800-1600 g/ha sebesar 160-171 ekor/rumpun. Pada perlakuan dosis anjuran $400 \mathrm{~g} / \mathrm{ha}, \mathrm{WBC}$ pada varietas Pelita meningkat tajam hingga mencapai 313 ekor/ rumpun.

Pada populasi generasi ke-2, jumlah WBC relatif tertinggi pada varietas Pelita diikuti Ciherang terutama pada pemberian dosis rendah $200 \mathrm{~g} / \mathrm{ha}$ sebesar 312-357 ekor/rumpun dan kontrol mencapai 430 ekor/rumpun. Puncak populasi nimfa pada perlakuan dosis ini umumnya dicapai pada minggu ke-5 dan minggu selanjutnya menjadi musnah karena kematian tanaman akibat hopperburn. Sebaliknya, jumlah WBC yang relatif masih tinggi bertahan pada varietas Ciherang dan Inpari 13 terjadi pada dosis aplikasi $800 \mathrm{~g} / \mathrm{ha}$, yaitu 217281 ekor/rumpun dan Pelita pada dosis 400-1600 g/ha, yaitu 200-205 ekor/rumpun. Puncak populasi nimfa pada perlakuan dosis tersebut pada varietas Ciherang dan Inpari13 umumnya terjadi pada minggu ke-6 dan ke-8, sedangkan pada varietas Pelita pada minggu ke-5.

Hal ini sesuai dengan hasil percobaan terdahulu bahwa perlakuan insektisida dapat meningkatkan populasi WBC pada tanaman varietas tahan Inpari 13 maupun agak tahan Ciherang yang tampak pada aplikasi di bawah dosis anjuran terjadi mulai generasi populasi I, 
A

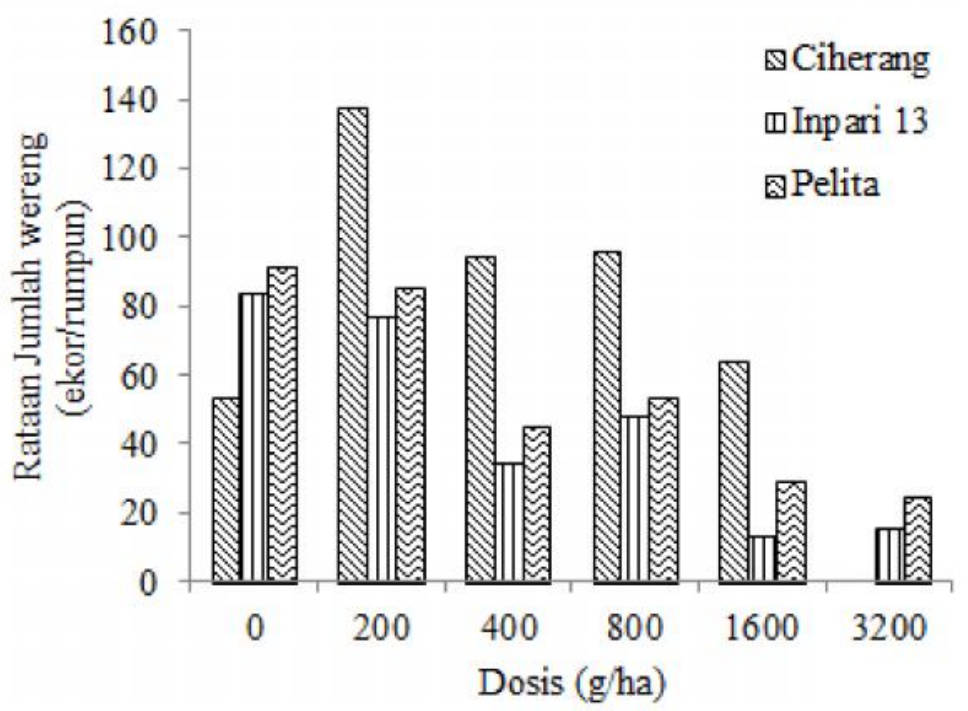

$\mathrm{B}$

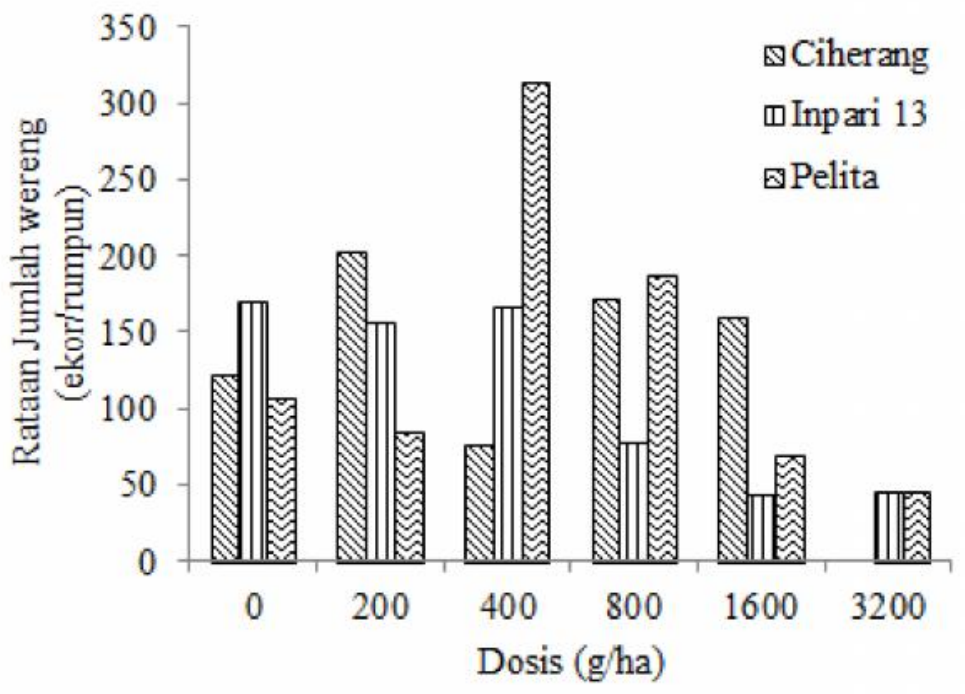

$\mathrm{C}$

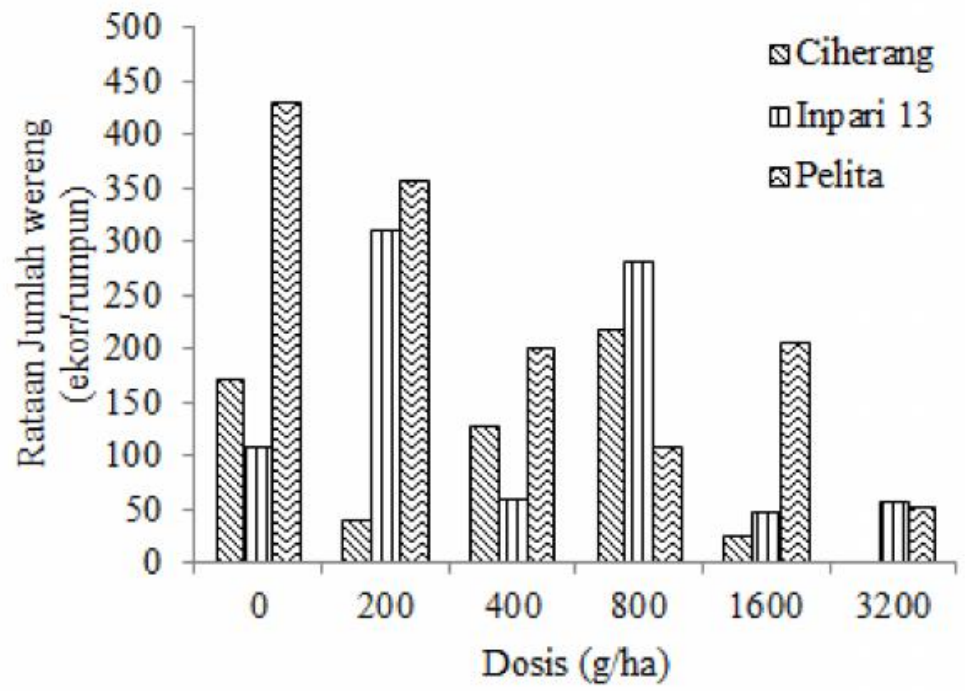

Gambar 1. Sintasan populasi nimta wereng coklat pada tiga varietas padi yang diaplikasi lima dosis imidakloprid.

(A) Dua minggu setelah aplikasi; (B) Puncak populasi generasi I; (C). Puncak populasi generasi II 
sedangkan pada aplikasi di atas dosis anjuran peningkatan populasi terjadi pada generasi populasi kedua. Pada varietas rentan Pelita, perkembangan jumlah nimfa meningkat drastis baru mulai tampak populasi generasi ke-2 disertai capaian puncak populasi lebih singkat yang hanya 5 minggu dan diikuti kematian tanaman. Azzam et al. (2011) menyatakan bahwa aplikasi insektisida berbahan aktif imidakloprid mempengaruhi perubahan kandungan hara yang bersirkulasi di dalam tanaman diantaranya $\mathrm{Ca}, \mathrm{Cu}, \mathrm{Fe}$, $\mathrm{Mg}, \mathrm{Mn}, \mathrm{Na}, \mathrm{K}$, dan $\mathrm{Zn}$ yang berimplikasi terhadap ketahanan tanaman dan pertumbuhan populasi wereng. Kandungan hara $\mathrm{K}$ yang tinggi pada tanaman dilaporkan dapat menghambat pertumbuhan populasi, sebaliknya kandungan Fe yang tinggi dapat meningkatkan populasi wereng punggung putih Sogatella furcifera (Horvath) (Salim \& Saxena, 1991). Menurut Buenaflor et al. (1981), perlakuan dekametrin pada kultivar padi rentan dapat meningkatkan kandungan asam amino atau menurunkan rasio $\mathrm{C} / \mathrm{N}$, sehingga menstimulasi perilaku makan dan mengakibatkan peningkatan populasi wereng. Pada dasarnya, kandungan asam amino tanaman varietas tahan wereng lebih rendah dari varietas rentan (Lu et al., 1982). Begitu pula pada varietas yang sangat tahan dilaporkan memiliki kandungan karbohidrat yang lebih rendah dibandingkan varietas rentan. Perlakuan insektisida dapat memicu lebih lanjut perubahan kualitas tanaman tahan yang berimplikasi pada peningkatan populasi WBC. Sesuai dengan hasil percobaan ini menunjukkan bahwa ketidakefektifan WBC terhadap insektisida meningkat lebih jauh saat wereng diinfestasikan pada tanaman varietas tahan Inpari 13 maupun agak tahan Ciherang.

Pengaruh Subletal Dosis Imidakloprid terhadap Produksi dan Abnormalitas Telur. Secara umum, perlakuan imidakloprid pada imago WBC yang sudah diaklimatisasikan satu musim tanam pada tanaman tahan Inpari 13 maupun rentan Pelita meningkatkan jumlah telur yang diletakkan, kecuali pada varietas Ciherang, jumlah telur lebih rendah dibandingkan kontrol (Tabel 3). Peningkatan relatif paling tinggi nyata 9 kali lipat ditemukan pada varietas Pelita dan 5 kali lipat pada Inpari 13, bila dibandingkan dengan masing-masing perlakuan kontrolnya. Saxena \& Pathak (1979) menyatakan bahwa perilaku peletakan telur wereng coklat tidak dipengaruhi oleh ketahanan tanaman, namun laju kematangan ovari pada wereng yang hidup pada varietas tahan lebih rendah bila dibandingkan dengan varietas rentan, juga pada beberapa varietas tahan dapat menyebabkan wereng gagal memproduksi telur. Varietas tahan seperti Inpari 13 memiliki mekanisme antisenosis yang menyebabkan penurunan aktivitas makan, sehingga dapat mengurangi jumlah asupan nutrisi yang dihisap oleh imago yang selanjutnya berpengaruh pada penurunan produksi telur (Rahmini et al., 2012). Seperti diuraikan sebelumnya bahwa insektisida dapat mempengaruhi perubahan kualitas tanaman. Dalam hal ini imidakloprid diduga memulihkan peningkatan produksi telur yang seharusnya tertahan akibat penghambatan makan pada varietas tahan. Keadaan yang berdeda pada wereng yang telah lama beradaptasi di lapangan yaitu pada varietas Ciherang, dalam hal ini terjadi penurunan peletakkan telur dibandingkan dengan kontrol. Bao et al. (2009) melaporkan bahwa imidakloprid dapat menurunkan fekunditas WBC yang berasal dari lapangan, namun menginduksi pembentukan makroptera.

Perlakuan imidakloprid pada imago wereng relatif tidak berpengaruh terhadap morfologi telur (Tabel 3). Bentuk telur abnormal hanya ditemui $0,2-1,4 \%$, selain itu seluruh telur normal dapat menetas menjadi nimfa. Abnormalitas bentuk telur yang dijumpai pada percobaan ini diduga dapat dipengaruhi oleh aplikasi imidakloprid atau dapat juga disebabkan faktor fisiologi yaitu asupan nutrisi dari tanaman varietas tahan yang tidak cukup bagi imago untuk meletakkan telur sehat. Hal ini tidak dapat dijelaskan dengan pasti. Kontsedalov et al. (2009)

Tabel 3. Pengaruh aplikasi imidakloprid terhadap peletakan telur dan abnormalitas bentuk telur wereng coklat pada 72 JSP

\begin{tabular}{lcc}
\hline Varietas & Jumlah telur \pm GB (butir/betina) & Abnormalitas telur $(\%)$ \\
\hline Inpari 13 & $57,4 \pm 47,8$ & 0 \\
Inpari 13* & $10,9 \pm 0,6$ & 1,4 \\
Ciherang & $43,6 \pm 16,6$ & 0 \\
Ciherang* & $86,4 \pm 14,8$ & 0 \\
Pelita & $336,0 \pm 25,4$ & 0,2 \\
Pelita* & $35,8 \pm 7,7$ & 0,04 \\
\hline
\end{tabular}

* Varietas perlakuan kontrol tanpa imidakloprid. 
menyatakan bahwa perlakuan insektisida spiromesifen dapat menyebabkan kerusakan korion pada telur Bemisia tabaci, sehingga struktur dalam telur menjadi bening, dan bentuk telur mengerut. Begitu pula de Moura (2011) melaporkan bahwa perlakuan abamektin dapat menyebabkan malformasi mikrofil dan kerusakan permukaan eksternal korion telur Chrysoperla external.

\section{SIMPULAN}

Insektisida imidakloprid memicu ketahanan WBC 13-234 kali lipat dari dosis anjuran. Dosis subletal imidakloprid cenderung meningkatkan jumlah populasi WBC pada varietas tanaman yang masih tahan di lapangan, seperti Ciherang dan Inpari 13. Dosis subletal imidakloprid berimplikasi pada peningkatan jumlah telur tetapi tidak berpengaruh terhadap abnormalitas morfologi telur WBC.

\section{SANWACANA}

Penulis mengucapkan terima kasih kepada Badan Litbang Pertanian, Departemen Pertanian atas dukungan dana penelitian melalui biaya penelitian KKP3T, SK Nomor 0060/018-09.0/-/2010.

\section{DAFTAR PUSTAKA}

Ahmed S, Nisar MS, Shakir MM, Imran M, \& Iqbal K. 2014. Comparative efficacy of some neonicotinoids and traditional insecticides on sucking insect pests and their natural enemies on BT-121 cotton crop. J. Anim. Plant Sci. 24(2): 660-663.

Azzam S, Yang F, Wu JC, Geng J, \& Yang GQ. 2011. Imidacloprid-induced transference effect on some elements in rice plants and the brown planthopper Nilaparvata lugens (Hemiptera: Delphacidae). Insect Sci. 18(3): 289-297.

Baehaki SE. 2011. Strategi fundamental pengendalian hama wereng batang coklat dalam pengamanan produksi padi nasional. Pengemb. Inov. Pertan. $4(1): 63-75$.

Bao H, Liu S, Gu J, Wang X, Liang X, \& Liu Z. 2009. Sublethal effects of four insecticides on the reproduction and wing formation of brown planthopper, Nilaparvata lugens. Pest Manag. Sci.65(2): 170-174.
Bottrell DG \& Schoenly KG. 2012. Resurrecting the ghost of green revolutions past: the brown planthopper as a recurring threat to high-yielding rice production in tropical Asia. J. Asia-Pac. Entomol. 15(1): 122-140.

Buenaflor HG, Saxena RC, \& Heinrichs EA. 1981. Biochemical basis of insecticide-induced brown planthopper resurgence. Int. Rice Res. News. 6(4): 13-14.

Chelliah S \& Heinrichs EA. 1980. Factors affecting insecticide-induced resurgence of the brown planthopper, Nilaparvata lugens on rice. Environ. Entomol. 9(6): 773-777.

Cheng Y, Shi ZP, Jiang LB, Ge LQ, Wu JC, \& Jahn GC. 2012. Possible connection between imidaclopridinduced changes in rice gene transcription profiles and susceptibility to the brown plant hopper Nilaparvata lugens Stål (Hemiptera: Delphacidae). Pestic. Biochem. Phys. 102(3): 213-219.

Cox C. 2001. Imidacloprid. J. Pestic. Reform 21(1): $15-21$.

Cruz AP, Arida A, Heong KL, \& Horgan FG. 2011. Aspects of brown planthopper adaptation to resistan rice varieties with the $B p h 3$ gene. Entomol. Exp. Appl. 141(3): 245-257.

de Moura AP, Carvalho GA, Cosme LV, Alves E, Botton M, \& Silva PS. 2011. Toxicological and ultrastructural analysis of the impact of pesticides used in temperate fruit crops on two population of Chrysoperla externa (Neuroptera: Chrysopidae). Rev. Bras. Entomol. 55(3):411418.

El-Hamady SE, Kubiak R, \& Derbalah AS. 2008. Fate of imidacloprid in soil and plant after application to cotton seeds. Chemosphere 71(11): 21732179 .

Fabellar LT \& Heinrichs EA. 1986. Relative toxicity of insecticides to rice planthoppers and leafhoppers and their predators. Crop. Prot. 5(4):254-258.

Fossen M. 2006. Environmental fate of imidacloprid. Environmental Monitoring Department of Pesticide Regulation. Sacramento, California. USA. http://www.cdpr.ca.gov/ docs/emon/pubs/ fatememo/Imidclprdfate2.pdf. Diakses 21 April 2015. 
Gao CX, Gu XH, Bei YW, \& Wang RM. 1988. Approach of causes on brown planthopper resurgence. Acta. Ecol. Sin. 8: 155-163.

Ghosh A, Samanta A, \& Chatterjee ML. 2014. Dinotefuran: a third generation neonicotinoid insecticide for management of rice brown planthopper. African J. Agric. Res. 9(8): 750754.

Gu XH, Bei YW, \& Wang RM. 1984. Effects of sublethal dosages of several insecticides on fecundity of the brown planthopper. Entomol. Knowl. 21: 276-279.

Heinrichs EA \& Mochida O. 1984. From secondary to major pest status: the case of insecticide-induce rice brown planthopper, Nilaparvata lugens, resurgence. Prot. Ecol. 7: 201-218.

[IRAC] Insecticide Resistance Action Committee. 2007. Resistance Management for Sustainable Agriculture and Improved Public Health. Crop Life International. http://www.irac-online.org/ documents/iiac-croplife-irm-booklet/?ext=pdf. Diakses 25 Januari 2015.

Kontsedalov S, Gottlieb Y, Ishaaya I, Nauen R, Horowitz R, \& Ghanim M. 2009. Toxicity of spiromesifen to the developmental stages of Bemisia tabaci biotype B. Pest Manag. Sci. 65(1): 5-13.

LeOra Software. 1987. POLO-PC User's Guide. Petaluma (US): LeOra Software.

Liu Z \& Han Z. 2006. Fitness costs of laboratoryselected imidacloprid resistance in the brown planthopper, Nilaparvata lugens Stål. Pest Manag. Sci. 62(3): 279-282.

Liu ZW, Han ZJ, Wang YC, Zhang LC, Zhang HW, \& Liu CJ. 2003. Selection for imidacloprid resistance in Nilaparvata lugens: Cross-resistance patterns and possible mechanisms. Pest Manag. Sci. 59(12): 1355-1359.

Lu ZM, Tang MY, \& Pang ZK. 1982. Resistant mechanism of hybrid rice to brown planthopper. Hun. Agr. Sci. 1(1): 9-12.

Matsumura M, Takeuchi H, Satoh M, Sanada-Morimura S, Otuka A, Watanabe T, \& Thanh DV. 2008. Species-specific insecticide resistance to imidacloprid and fipronil in the rice planthoppers Nilaparvata lugens and Sogatella furcifera in East and South-East Asia. Pest Manag. Sci. 64(11): 1115-1121.
Matsumura M, Takeuchi H, Satoh M, Sanada-Morimura S, Otuka A, Watanabe T, \& Thanh DV. 2009. Current status of insecticide resistance in rice planthoppers in Asia. In: Heong KL \& Hardy B (Eds.) Planthoppers: New Threats to the Sustainability of Intensive Rice Production Systems in Asia. pp. 233-243. International Rice Research Institute, Los Banos.

Nagata T \& Hayakawa T. 1998. Activity of aconitic acids and oxalic acid on brown planthopper, Nilaparvata lugens (Stål) and green rice leafhopper, Nephotettix cincticeps (Uhler). Jpn. J. App. Entomol. Zool. 42(3): 115-121.

Nauen R \& Denholm I. 2005. Resistance of insect pests to neonicotinoid insecticides: current status and future prospects. Arch. Insect Biochem. Physiol. 58(4): 200-215.

Rahmini, Hidayat P, Ratna ES, Winasa IW, \& Manuwoto S. 2012. Respon biologi wereng batang coklat terhadap biokimia tanaman padi. Penel. Pertan. Tan. Pang. 31(2): 117-123.

Raymond B, Wright DJ, \& Bonsall MB. 2011. Effects of host plant and genetic background on the fitness costs of resistance to Bacillus thuringiensis. Heredity 106(2):281-288.

Reissig WH, Heinrichs SEA, \& Valencia SL. 1982. Effects of insecticides on Nilaparvata lugens and its predators: Spider, Microvelia atrolineata, and Cyrtorhinus lividipennis. Environ. Entomol. 11(1):193-199.

Salim M \& Saxena RC. 1991. Nutritional stresses and varietal resistance in rice: Effects on whitebacked planthopper. Crop. Sci. 31(3): 212-219.

Saxena RC \& Pathak MD. 1979. Factors governing susceptibility and resistance of certain Ice varietas to the brown planthopper. In: Brady NC (Eds.). Brown Planthopper: Threat to Rice Production in Asia. pp. 303-317. International Rice Research Institute, Los Banos.

Sogawa K \& Pathak MD. 1970. Mechanisms of brown planthopper resistance in Mudgo variety of rice (Hemiptera: Delphacidae). Appl. Entomol. Zool. 5(3): 145-158.

Suprihatno B, Daradjat AA, Satoto, Baehaki SE, Widiarta IN, Setyono A, Indrasari SD, Lesmana OS, \& Sembiring H. 2009. Deskripsi Varietas 
Padi. Balai Besar Penelitian Tanaman Padi. Subang.

Wang YC, Fang JQ, Tian XZ, Gao BZ, \& Fan YR. 1994. Studies on resurgence question of planthoppers induced by deltamethrin and metamidophos. Entomol. Knowl. 31(5): 257-262.

Wang YH, Gao CF, Zhu YC, Chen J, Li WH, Zhuang YL, Dai DJ, Zhou WJ, Ma CY, \& Shen JL. 2008. Imidacloprid susceptibility survey and selection risk assesment in field populations of Nilaparvata lugens (Homoptera: Delphacidae). J. Econ. Entomol. 101(2): 515-522.

Wen Y, Liu Z, Bao H, \& Han Z. 2009. Imidacloprid resistance and its mechanisms in field populations of brown planthopper, Nilaparvata lugens Stål in China. Pestic. Biochem. Phys. 94(1): 36-42.

Wu JC, Qiu HM, Yang GQ, Liu JL, Liu GJ, \& Wilkins RM. 2004. Effective duration of pesticide-induced susceptibility of rice to brown planthopper (Nilaparvata lugens Stål, Homoptera: Delphacidae) and physiological and biochemical changes in rice plants following application. Int. J. Pest Manage. 50(1):55-62.

Wu JC, Xu JX, Yuan SZ, Liu YL, Jiang YH, \& Xu JF. 2001. Pesticide-induced susceptibility of rice to brown planthopper Nilaparvata lugens. Entomol. Exp. App. 100 (1): 119-126.

Yang YJ, Dong BQ, Xu HX, Zheng XS, Heong KL, \& Lu ZX. 2014. Susceptibility to insecticides and ecological fitness in resistant rice varieties of field Nilaparvata lugens Stål population free from insecticides in laboratory. Rice Sci. 21(3): 181186.

Yin JL, Xu HW, Wu JC, Hu JH, \& Yang GQ. 2008. Cultivar and insecticide applications affect the physiological development of the brown planthopper, Nilaparvata lugens Stål (Hemiptera: Delphacidae). Environ. Entomol. 37(1): 206-212. 